\title{
The Introduce of Various Pseudokarst Features in Alvand Granitic Rocks, Hamedan, west of Iran
}

\author{
Khanlari G. H.; Geology Department, Bu-Ali Sina \\ University, Hamedan, Iran \\ Fereidooni D.; School of Earth Sciences, Damghan \\ University, Damghan, Iran
}

Received: 10 May 2013

Revised 7 April 2015

\begin{abstract}
This research focuses on the identification and description of various features of pseudokarst in different parts of Alvand granitic batholith, Hamedan, west of Iran. In the literature, karst features have been presented as specific types of terrains or landscapes with particular characteristics suites of well-known surface and subsurface dissolutional forms. Whereas, pseudokarst refers to non-dissolutional surface or subsurface features and landforms created in different areas such as slopes, coastal lines crushed stone areas, lava tubes and permafrost regions. In this research, a comprehensive field investigation program has been carried out. During the field investigations, the most important features of pseudokarst in Alvand granitic batholith have been recognized and classified. Results show a wide range of pseudokarst features in the Alvand granitic rock masses. These landforms are created by erosion, weathering processes and some
\end{abstract}

Corresponding author khanlari_reza@yahoo.com 
holes caused by rock block movements in the rock slopes. Some of the most important forms and features of the pseudokarst in the studied area contain tafoni, genama, pseudokarren, talus caves, caves associated with the residual blocks and erosional forms along joints and fractures within the granitic rock masses.

Keywords: Alvand granite, Pseudokarst, Caves, Tafoni, Genama

\section{Introduction}

During the last five decades, the study of pseudokarstic features has been done by various researchers such as Zeng, 1960; Ritchot, 1975; Twidale,1982; Thomas, 1994; Huang, 1996; Halliday, 2007; Wei and Zhang, 2007; Luo et al., 2007; Chen, 2007 and Chen 2009. Karst conditions are characterized by a variable surface landforms and subsurface features due to the dissolution of soluble rocks such as limestone, gypsum or salt. Therefore, karstic features are distinguished from pseudokarst types by solution process. In other words, true karstic features may be excavated entirely by aqueous solution, or other processes may contribute largely to their dimensions; but where this latter applies, solution plays an essential precursor or trigger role (Wray, 2003).

A working session of the 1997 International Congress of Speleology concluded that pseudokarsts are landscapes with morphologies resembling karst, and/or may have a predominance of subsurface drainage through conduit type voids, but lack the element of long-term 
evolution by solution and physical erosion (Kempe and Halliday, 1997).

As a result, pseudokarst condition, resemble karst but were not caused by the dissolution of rocks (Technos, 2005). The major factors in occurrence of pseudokarst landscapes and land forms are corrosion and erosion (weathering processes). In other words, non-karst caves developed due to various processes in different rocks and in almost every region. Some of them reflect the processes responsible for their development and thus they are suitable for geological and geomorphologic studies (Urban, 2005). According to Halliday (2007) the most important types of pseudokarst are as rheogenic, glassier, badland and piping, permafrost, talus, crevice, compaction and consequent pseudokarsts.

Pseudokarst features typically are developed in lava, unconsolidated sediments, volcanic ash, talus, ice, and permafrost areas (Kempe and Halliday 1997). Also, pseudokarst is most highly developed in basalt flows with lava tubes (Halliday, 2007). In addition, the major causes forming pseudokarst landscapes in quartzose rocks, especially granites are the result of post-genetic weathering and erosional processes (Vaquiro Rodriguez, 2004). More commonly, pseudokarst features are the result of man's activities such as regional subsidence due to groundwater or petroleum withdrawal, along with collapse due to mining and leaky pipes and sewers (Olson, 2001).

Hamedan is located in west of Iran and is one of the areas that granites are most widely distributed, with a total area of 400 square kilometers (Sepahi-Gero 1999). This area has a high potential of 
pseudokarst occurrence. Alvand granitic batholith is exposed by weathering and erosion processes in the earth surface. The results of field observation on different parts of the plutonic batholite indicated that various pseudokarst features with different size are created and developed. Since the granitic rocks are used in some of engineering projects such as foundations, dam sites and tunneling. Therefore, the study of features affected on engineering properties of rocks is important.

\section{Geological setting}

The study area with longitude of $48^{\circ} 10^{\prime} \mathrm{E}$ to $48^{\circ} 35^{\prime} \mathrm{E}$ and latitude of $34^{\circ} 30^{\prime} \mathrm{N}$ to $34^{\circ} 52^{\prime} \mathrm{N}$, is considered as one of the most important plutonic rock masses of Iran. It's out crop is about $400 \mathrm{~km}^{2}$ which is largest plutonic rock mass in Iran and Sanandaj-Sirjan Metamorphic Belt (SSMB). This zone is characterized by the predominance of metamorphic rocks, accompany with the sedimentary and magmatic rocks.

Alvand batholith consist of a mafic part (gabbro-diorite-tonalite), intermediate (granite-granodiorite porphyroids), and hololeucocratic granitoids. Previous studies have shown that S-type granitegranodiorites are mostly per-aluminous and calc-alkaline, the gabbrodiorite-tonalite suite is mostly metaluminous and tholeiitic to calcalkaline (Sepahi-Gero 2008).

The metamorphic rocks adjacent to this granite rock mass are consisting pelitic hornfels and schist. The geology deposits close to the north and east side of the studied area are the quaternary 
alluviums. Figure 1 shows geological map of the study area and its location in Iran map.

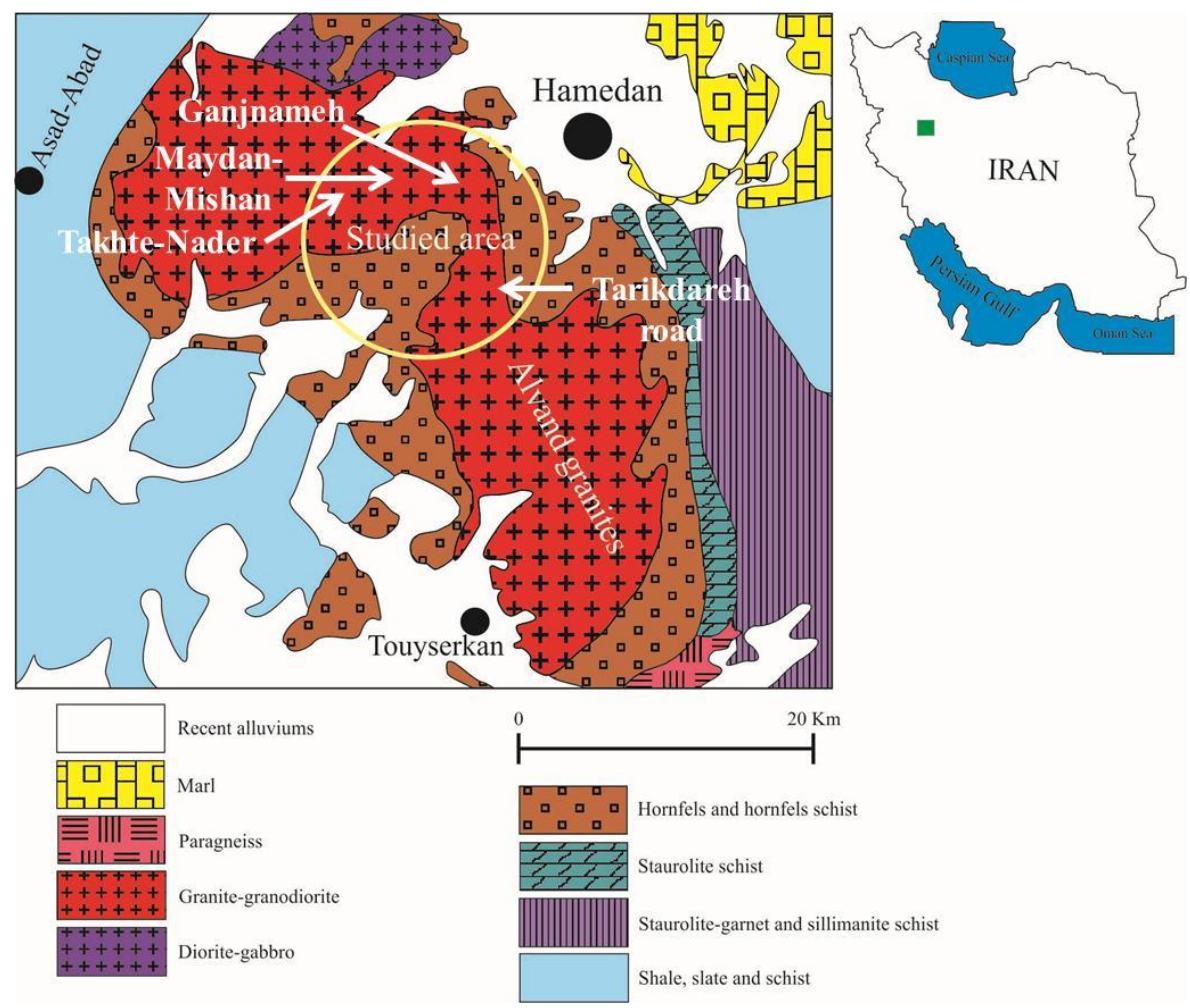

Figure1. Geological map of the study area (GSI, 1977)

\section{Methodology}

This research work is based on both literature reviews and field investigations. In the literature, different sources of information such as papers, theses, topographical and geological maps of Alvand region were collected and studied. The field investigations have been carried out by considering different forms and features of pseudokarst in the 
various parts of Alvand region such as Ganjnameh, Maydan-Mishan, Takhte-Nader and Tarikdareh road. During the field investigations, different pseudokarst features that are created by weathering and erosion of the rock masses and some caves caused by in situ or transported rock blocks have been identified and classified.

\section{Pseudokarst in granitic rocks}

More than $15 \%$ of the earth continent surface is exposed by granite, displaying as diverse landscapes, such as boulders, pediments, bornhardts, basins, tafoni and so on. Granite landscapes have been impacted by both the paleo-climate and current climate (Chen et al. 2009). The most important types of pseudokarst in granitic rock masses are as follows:

\section{Caves induced by stress}

Granitic magmas on their way to the surface are exposed to lithostatic or confining and tectonic or direct stresses. The first one is present everywhere in the lithosphere. The tectonic stress is generated during the magma emplacement and is able to produce structures in the rock that are affected under different stress regimes: plastic, ductile, brittle and elastic according to the magma consolidation/cooling grade (Arzi 1978; Twidale and Vidal Romani 1994). The stresses impose structures and other mechanical discontinuities, such as shear bands, fractures, faults and diaclases on the affected material (Roman Berdiel, 1995; Petford 2003; Aurejac et al. 2004). These structures 
mainly affect the outer zones of the magmatic body and are due to the interactions between the magma and the walls of the injection conduits (host rock) (Vidal Romani and Twidale 1999). So, during the emplacement, rock protoclastic fractures (brittle strain) are developed in these peripheral zones (Vidal Romani and Vaqueiro Rodriguez, 2007).

Generally, in areas which magma is injected into the earth crust and igneous rock masses are shaped, there are various kinds of stresses with various origins which are creating different structures within these rocks. If igneous rock mass has been exposed, weathering effect on these structures creates pseudokarst. According to Vidal Romani and Vaqueiro Rodriguez (2007), these stresses are as follows:

a. Stresses of cooling and crystallization of magma: During cooling and crystallization of magma its volume decreases can create stretch fractures in igneous rocks.

b. Compression stresses of magma to intrusive rocks: This stresses creates structures and joints in rocks. If magma crystallized, fractures and joints are shaped in its external parts.

c. Stress concentration: Concentration of stress in intrusive rock masses in caused by tectonic forces because most igneous rocks injected in active tectonic site.

d. Stresses induced by unloading in intrusive rock masses: Because of watering and erosion, overburden materials eliminated gradually. This creates vertical stresses on rock surface. These stresses create joints in parallel with surface of rock mass which are known as stretch crevices released tension cracks. 


\section{Caves caused by weathering}

The inside wall or vault may develop alveolus, mamillated (convex relief) or scalloped (concave relief) forms (Twidale and Vidal Romani 2005) and also negative exfoliation forms (Vidal Romani 1985). According to Vaqueiro Rodriguez (2004), the forms developed by preferential weathering inside horizontal joints are mainly overexcavated walls, pseudo-flared forms, feeding and drainage tubes. Preferential weathering inside vertical joints produces incipient pseudokarren-type forms, and also tafoni, and gnamma forms.

According to Vidal Romani and Vaqueiro Rodriguez, 2007, the types of granite caves are classified as follows:

a. Caves developed along major fracture planes: Weathering is essentially due to mineral washing, yielding to further widening of the fracture.

b. Caves associated with residual blockfields: Here the finer fractions of the granite regolith, if exist, have been washed away and leaving the coarse fractions-blocks and in situ boulders.

c. Tafoni is linked to the elastic deformation stage of the massif, though similar types of cavities have been attributed to epigenic environments (Twidale 1982, 2002; Migon, 2006).

\section{Caves caused by groundwater activities}

Effects of ground water on granitic rocks are brief in three steps (Vidal Romani and Vaqueiro Rodriguez, 2007):

a. Weathering of rock by groundwater. 
b. Recharging weathered aggregates by groundwater from joints and fractures.

c. Creating free groundwater flow and more physical or mechanical erosion or development of pseudokarst caves.

\section{Pseudokarst in Alvand granites}

Field investigations in various parts of Alvand granites show that pseudokarst features are formed by weathering, destruction, erosion and act of freezing and thawing processes. Different types of recognized pseudokarst in Alvand granites are as follows:

\section{Caves developed by fractures and joints}

Granitic rock masses have generally had two or three joint sets because; they are formed in areas with active tectonics. Also, the presence of released tensile joints in the granitic rocks is prevalent. Weathering by mineral washing from fracture and joint surfaces increases opening or aperture of fractures which leads to develop of caves, voids and spaces within the rock masses. Some of these features are recognized as pseudokarst which is observable along vertical and horizontal fractures. Depth and lateral spread of these features are related to the extension of joints or fractures in the rock masses. Figure 2 shows two samples of these features between Maydan-Mishan and Takhte-Nader areas in Alvand granites. 


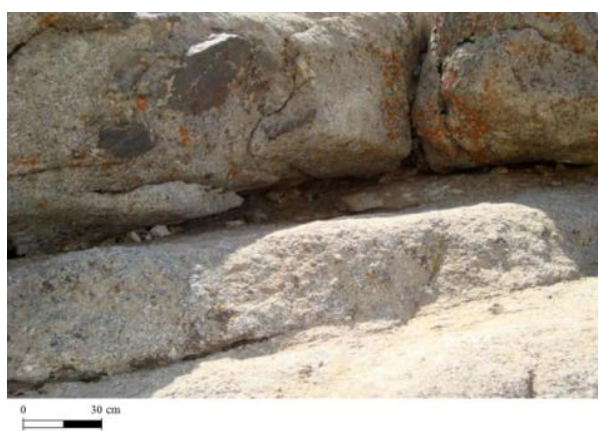

(a)

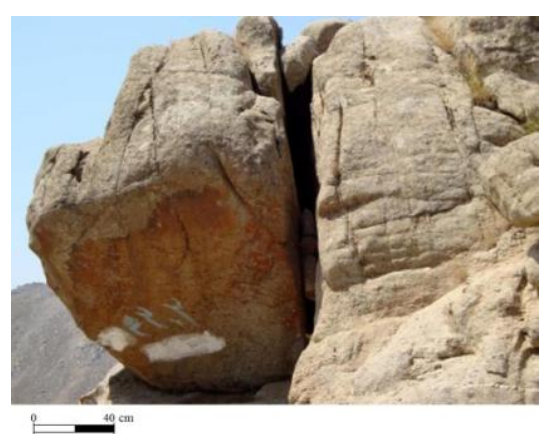

(b)

Figure2. Caves developed along a) horizontal, b) vertical fractures and joints

\section{Caves associated with residual blockfields}

In areas which igneous rock mass is steeped, erosion and transportation of fine-grain aggregates create pores and caves between residual blocks of rock masses. These features generally have irregular shape, non-uniform distribution and small size. A sample of residual blockfields pseudokarst is presented in Figure 3.

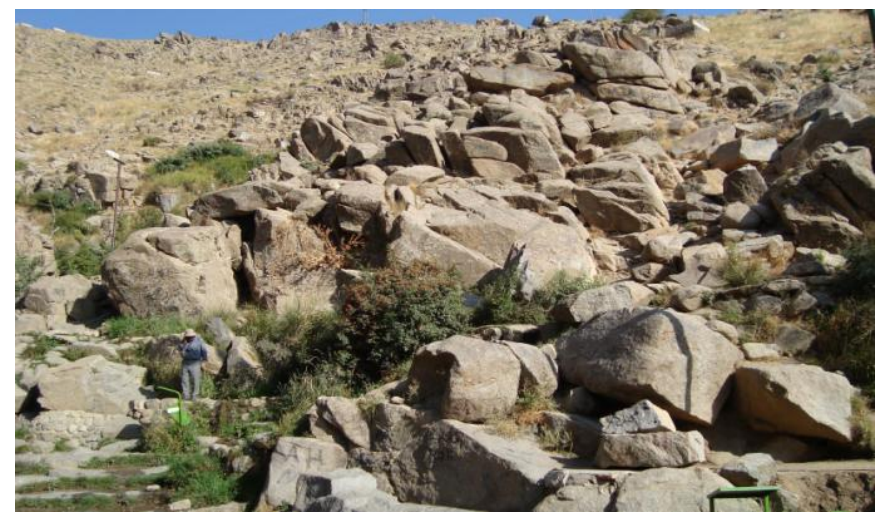

Figure3. Caves associated with residual blockfields in Alvand granites 


\section{Talus caves}

Accumulation of weathered rock blocks and materials in slopes sometimes creates a major form of pseudokarst known as talus pseudokarst. This feature has been occurred in granitic rock masses so that leads to beautiful caves. The most important factors forming these caves are slipping and sliding of rock blocks and also gratifications of granites. Number and volume of created caves are related to the volume and particle size of slide materials, respectively. Figure 4 shows a sample of this type of caves in Alvand granites.

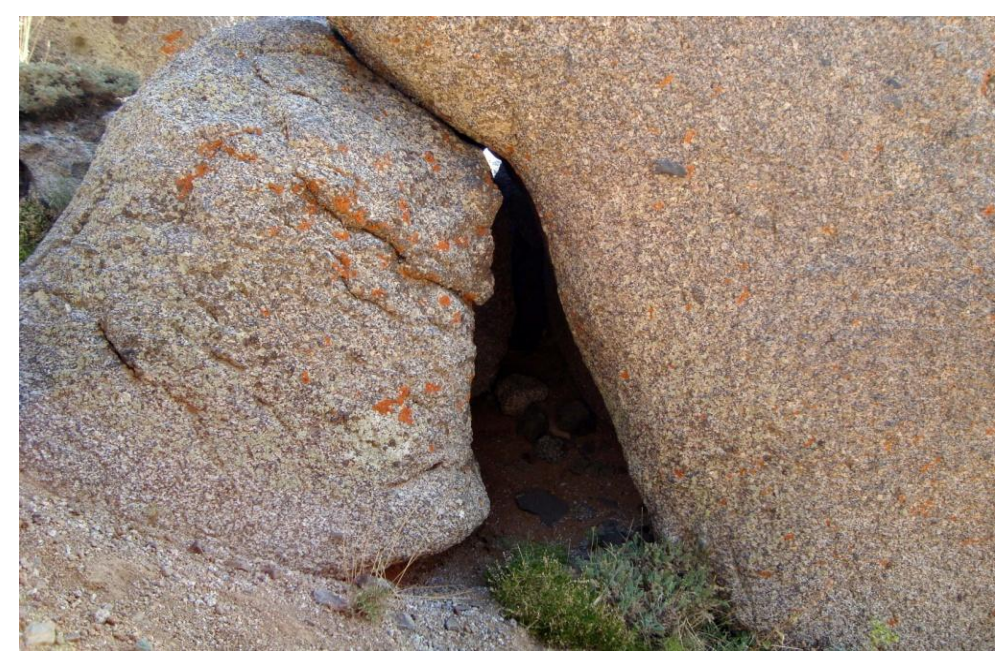

Figure4. A sample of talus pseudokarst in Alvand granites

\section{Tafoni}

The tafoni term refers to a cavern or hollow developed inside a fracture-defined block. The inside wall or vault may develop alveolus (honeycomb structure), mamillated (convex relief) or scalloped 
(concave relief) forms and also negative exfoliation forms. These features are deep and large forms of pseudokarstic related to weathering process on the surface of stable rock blocks. Their sizes are large so that a person can be placed within them. Commonly, wall surfaces of tafonis are smooth. Figure 5 shows three samples of tafonis in Ganjnameh and Maydan-Mishan of Alvand region.

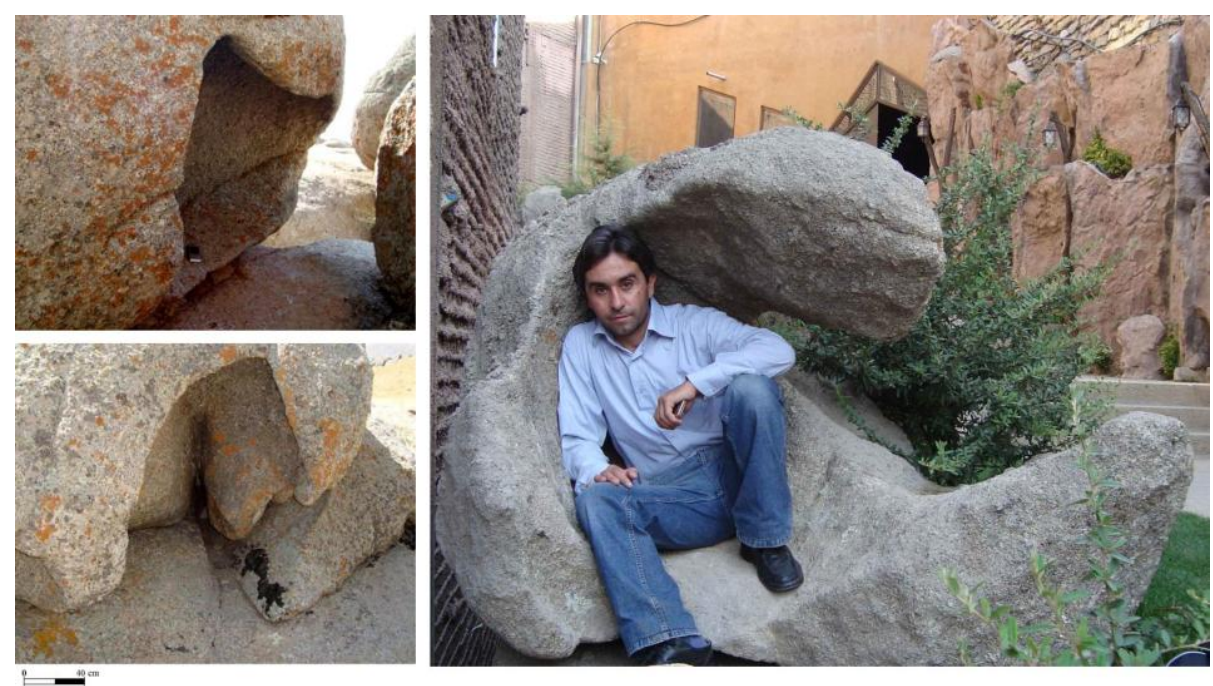

Figure5. Two samples of tafoni in Maydan-Mishan of Alvand granites

\section{Gnamma}

These features are smaller than tafoni and resulted from weathering or erosion in surface of rock blocks or rock masses. They have circular or ellipse crater and are visible as pan and pot types. Pantypes have less depth with larger diameter but pot-types have more depth with small diameter. Figure 6 shows a pan-type in the first part of Tarikdareh road in Alvand batholith with about $50 \mathrm{~cm}$ diameter. 
Figure 7 shows two samples of pot-type gnamma in Gangnameh and Maydan-Mishan in Alvand region.

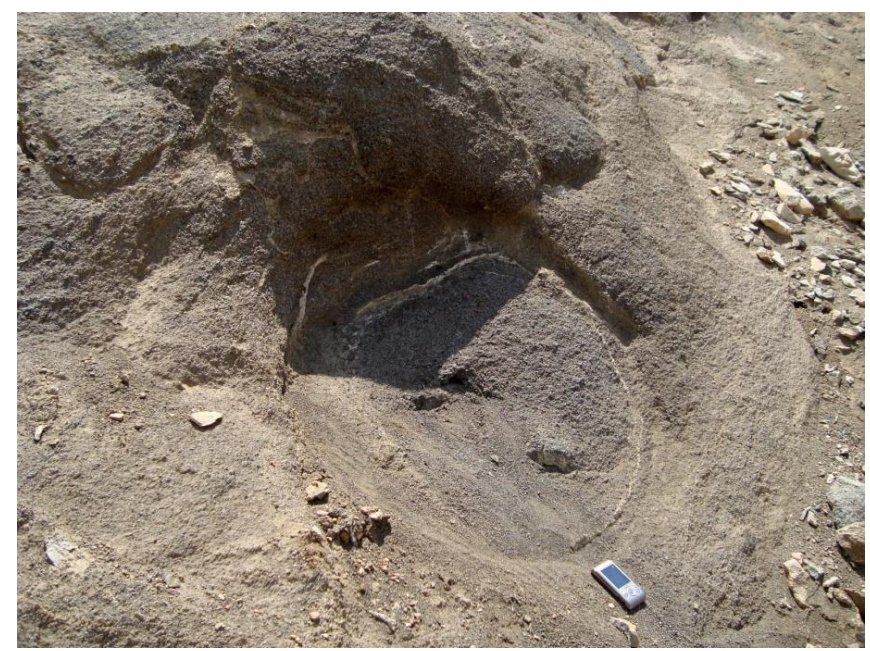

Figure6. A sample of pan-type gnamma in the first part of Tarikdareh road
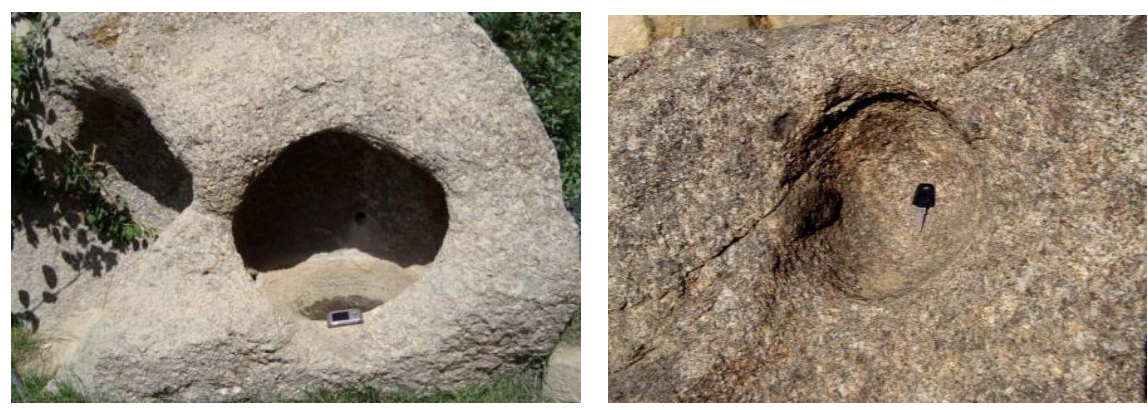

Figure7. Two samples of pot-type gnamma in Maydan-Mishan

\section{Caves associated with weathering and erosion of enclaves}

During injection of magma within the adjacent rocks, other materials with different compound are entered into the magma. After crystallization they are called enclave. Enclaves in Alvand granites are 
composed of maphic rocks which show more sensitivity to weathering and erosion processes. So, they can erode, displace and create the caves known as pseudokarst. These features have different dimensions related to the size of enclaves and generally are smaller than tafonis. The remains of enclaves are generally seen in the voids or caves. Figure 8 shows two samples of small caves in Alvand granites in Maydan-Mishann and Takhte-Nader region.

\section{Pseudokarren}

These features are small karrens in the surface of rock masses which their forming is due to non-homogeneity on the surface of rock materials. In other words, pseudokarrens caused by differential weathering in minerals composing granitic rocks. In this case, some of the minerals are more sensitive to weathering than others. For example, feldspars are more weatherable and resistant minerals like quartz are striking. These forms are more observable in porphyroid granites. Figure 9 shows a sample of pseudokarren in Alvand porphyroid granites.
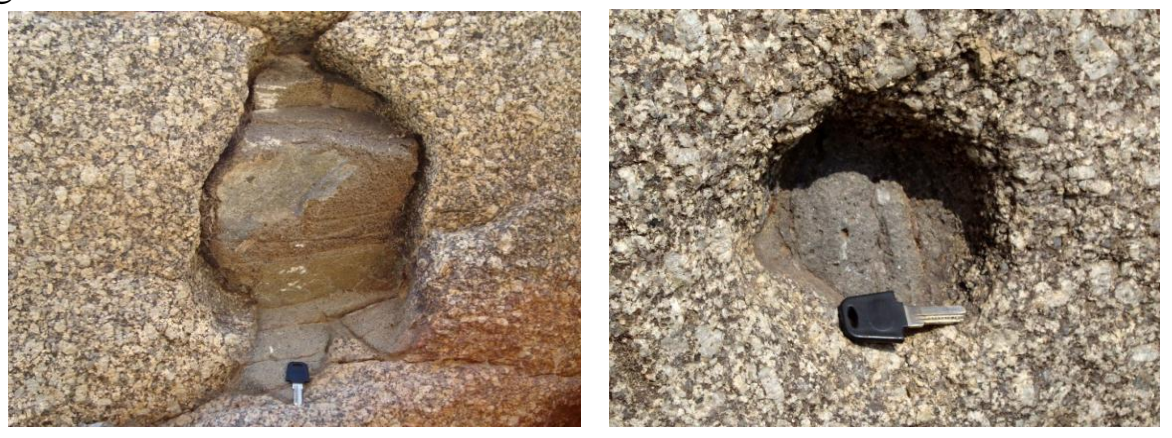

Figure8.Two samples of caves associated with weathering and erosion of enclaves in Maydan-Mishan and Takhte-Nader region 


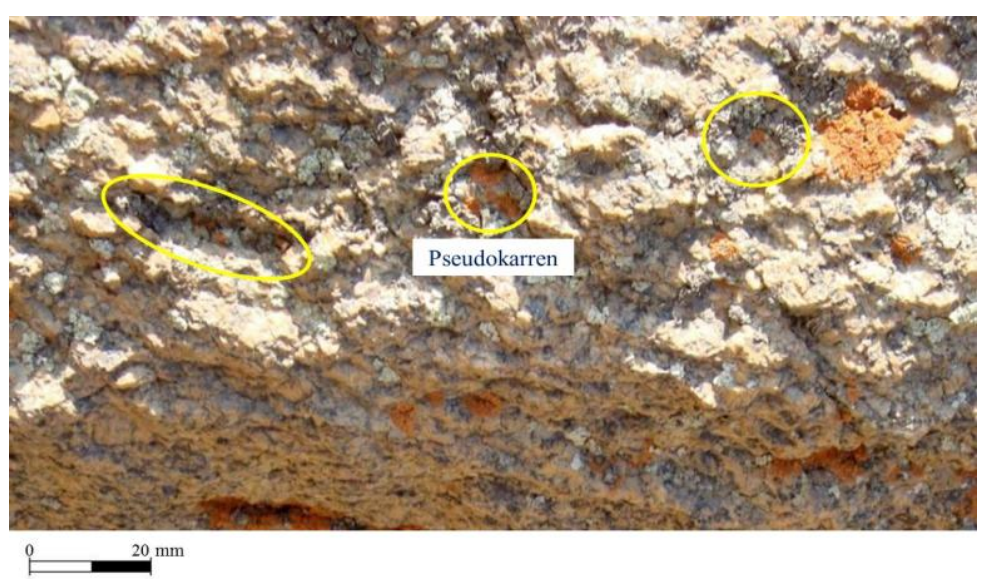

Figure9. Some samples of pseudokarren of Alvand granites

\section{Discussion and conclusion}

Alvand granite is the biggest intrusive igneous rock mass in west of Iran. It concludes different features of pseudokarst such as caves and holes developed along fractures and joints resulted by weathering and erosion processes. These features are exposed in most parts of Alvand batolith. From a geomorphological and engineering geomorphological point of view these features are very important. Some parameters such as lithology, climate, fractures, joints and enclaves are affected factors on development of pseudokarst features in this region.

Despite of karstic forms which are created by dissolution process, pseudokarst features in Alvand granite rock masses are formed by some of surface processes such as weathering, erosion and ground water activities. The most important pseudokarst features and caves founded in Alvand granites are consist of caves developed along fractures and joints, the caves associated with residual blockfields, 
talus caves, tafoni, gnamma, pseudokarren, caves associated with weathering and pseudokarst features due to the erosion of enclaves.

\section{References}

1. Arzi A.A., "Critical phenomena in the rheology of partially melted rocks", Tectonophysics 44 (1978) 173-184.

2. Aurejac J.B., Gleizes G., Diot H., Bouchez J. L., "Le complexe granitique de Querigut (Pyrenees, France) re-examine par la technique de l'ASM: Un pluton syntectonique de la transpression dextre hercynienne", Bull. Soc. Geol. France 2 (2004) 157-174.

3. Chen A.Z., "Some problems of granite geomorphological landscapes", Geological Review, 53 (suppl.) (2007) 1-8.

4. Chen Y., Cui Z., Yang J., "Influence of climate and tectonic movements on granite landforms in China", J. Geogr. Sci. 19 (2009) 587-599.

5. GSI, (Geological Society of Iran), "Geological quadrangle map of Iran", No. D6, Scale 1:250000, Printed by Offset Press Inc., Tehran (1977).

6. Halliday W.R., "Pseudokarst in the $21^{\text {st }}$ century" Journal of Cave and Karst Studies 69, No. 1 (2007) 103-113.

7. Huang Z.G., "Red Residuum in South China" Beijing: China Ocean Press (1996).

8. Kempe S., Halliday W.R., "Report on the discussion on pseudokarast", Proceedings of the 12th International Congress of Speleology, v. 6 Basel, Switzerland, Speleoprojects (1997).

9. Luo Z.H., Huang Z.M., Ke S., "An overview of granitoid" Geological Review, 53 (suppl.) (2007) 180-226.

10. Migon P., "Granite landscapes of the World", Oxford University Press Great Britain (2006). 
11. Olson R., "Karst Landscapes and the Importance of Three Dimensional Data in Protection of Cave and Karst Resources", U.S. Geological Survey Karst Interest Group Proceedings, Water-Resources Investigations Report 01-4011 (2001) 1-7.

12. Petford N., "Rheology of granitic magmas during ascent and emplacement", Annual Review Earth Planetary Science 31 (2003) 399-427.

13. Ritchot G., "Essais de Géomorphologie Structurale" Québec: Presses Universitaires Laval, (1975).

14. Roman, Berdiel M.T., "Mecanismes dintrusion des granites supracrustaux", Modeles analogiques et exemples naturels. Memoire. Geosciences Rennes. Rennes, France, 62 (1995) 1-258.

15. Sepahi-Gero A.A., "Petrology of Alvand Plutonic with emphasis on granitoieds", $\mathrm{PhD}$ thesis on petrology, Tarbiat Moalem university, Tehran, Iran (1999).

16. Sepahi-Gero A.A., "Typology and petrogenesis of granitic rocks in the Sannandaj-Sirjan metamorphic belt, Iran: with emphasis on the Alvand plutonic complex", N. Jb. Geol. Palaont. Abh, 247 (3) (2008) 295-312.

17. Technos Inc., "Characterizing Karst and Pseudokarst" Website. www.technos-inc.com, Volume 4, Issue 2 (2005) 1-12.

18. Thomas M.F., "Geomorphology in the Tropics: A study of Weathering and Denudation in Low Latitude", Chichester: John Wiley \& Sons (1994).

19. Twidale C.R., "Granite Landforms", Amsterdam: Elsevier (1982).

20. Twidale C.R., "The two stage concept of landform and landscape development involving etching: origin, development and implications of an idea", Earth Science Reviews 57 (2002) 37-74.

21. Twidale C.R., Vidal Romani J.R., "Landforms and Geology of Granite terrains", Ed. Balkema, the Netherlands, Amsterdam (2005). 
22. Twidale C.R., Vidal Romani J.R., "On the multistage development of etch forms",Geomorphology 11 (1994) 157-186.

23. Twidale C.R., "Granite Landforms", Elsevier Publishing Company, Amsterdam (1982).

24. Urban J., "Pseudokarst caves as an evidence of sandstone forms evolution-a case study of Niekłań, the Świętokrzyskie Mts., central Poland", Ferrantia 44 (2005)181-185.

25. Vaquiro Rodriguez M., "Karst in siliceous rocks:Pseudokarst landforms and caves in the quartz dyke of Pico Sacro (Boqueixon, Galicia)", Caderno Lab. Xeoloxico de Laxe Coruna. 29 (2004) 247-264.

26. Vidal Romani J.R., Vaqueiro Rodriguez M., "Types of granite cavities and associated speleothems: genesis and evolution", Nature Conservation 63 (2007) 41-46.

27. Vidal Romani J.R., "El Cuaternario de la provincia de La Coruna. Modelos elasticos de formacion de cavidades", Servicio de Publicaciones. Universidad Complutense de Madrid. Serie Tesis Doctorales, Madrid (1985).

28. Vidal Romani J.R., Twidale C.R., "Sheet fractures, other stress forms and some engineering implications", Geomorphology 31(1-4) (1999) 13-27.

29. Wei H.R., Zhang Z.C, "Types of granite landscapes and discussions on their formation processes", Geological Review, 53(suppl.) (2007) 147159.

30. Wray Robert A.L., "Quartzite dissolution: karst or pseudokarst?", Speleogenesis and Evolution of Karst Aquifers 2 (2003) 1-9.

31. Zeng Z.X., "Lithogeneous Topography", Beijing: Geological Publishing House (1960). 